\title{
Altered brain gene expression but not steroid biochemistry in a genetic mouse model of neurodevelopmental disorder
}

\author{
Simon Trent ${ }^{1}$, Jonathan P Fry ${ }^{2}$, Obah A Ojarikre ${ }^{3}$ and William Davies ${ }^{1,4,5^{*}}$
}

\begin{abstract}
Background: The $39, \mathrm{X}^{\gamma^{*}} \mathrm{O}$ mouse, which lacks the orthologues of the ADHD and autism candidate genes STS (steroid sulphatase) and ASMT (acetylserotonin O-methyltransferase), exhibits behavioural phenotypes relevant to developmental disorders. The neurobiology underlying these phenotypes is unclear, although there is evidence for serotonergic abnormalities in the striatum and hippocampus.

Methods: Using microarray and quantitative gene expression analyses, and gas chromatography-mass spectrometry, we compared brain gene expression and steroid biochemistry in wildtype $(40, X Y)$ and $39, X^{Y^{*}} \mathrm{O}$ adult mice to identify non-obvious genetic and endocrine candidates for between-group differences in behaviour and neurochemistry. We also tested whether acute STS inhibition by COUMATE in wildtype $(40, X Y)$ adult male mice recapitulated any significant gene expression or biochemical findings from the genetic comparison. Data were analysed by unpaired $t$-test or Mann Whitney U-test depending on normality, with a single factor of KARYOTYPE.

Results: Microarray analysis indicated seven robust gene expression differences between the two groups (Vmn2r86, Sfi1, Pisd-ps1, Tagap1, C1qc, Metap1d, Erdr1); Erdr1 and C1qc expression was significantly reduced in the 39, $X^{Y^{*}} \mathrm{O}$ striatum and hippocampus, whilst the expression of Dhcr7 (encoding 7-dehydrocholesterol reductase, a modulator of serotonin system development), was only reduced in the $39, X^{Y^{*}} \mathrm{O}$ hippocampus. None of the confirmed gene expression changes could be recapitulated by COUMATE administration. We detected ten free, and two sulphated steroids in $40, X Y$ and $39, X^{Y^{*}} \mathrm{O}$ brain; surprisingly, the concentrations of all of these were equivalent between groups.

Conclusions: Our data demonstrate that the mutation in $39, Y^{Y *} \mathrm{O}$ mice: i) directly disrupts expression of the adjacent Erdr1 gene, ii) induces a remarkably limited suite of downstream gene expression changes developmentally, with several of relevance to associated neurobehavioural phenotypes and iii) does not elicit large changes in brain steroid biochemistry. It is possible that individuals with STS/ASMT deficiency exhibit a similarly specific pattern of gene expression changes to the $39, Y^{Y *} \mathrm{O}$ mouse, and that these contribute towards their abnormal neurobiology. Future work may focus on whether complement pathway function, mitochondrial metabolism and cholesterol biosynthesis pathways are perturbed in such subjects.
\end{abstract}

Keywords: Acetylserotonin O-methyltransferase, COUMATE, Steroid sulphatase, 39, $X^{Y^{*}} \mathrm{O}$

\footnotetext{
*Correspondence: daviesw4@cardiff.ac.uk

${ }^{1}$ Neuroscience and Mental Health Research Institute, Cardiff University, Cardiff, UK

${ }^{4}$ Medical Research Council Centre for Neuropsychiatric Genetics and

Genomics, Cardiff University, Cardiff, UK

Full list of author information is available at the end of the article
} 


\section{Background}

Autism spectrum disorders (ASDs) and Attention Deficit Hyperactivity Disorder (ADHD) exhibit partially overlapping neurobehavioural symptoms, frequent comorbidity, altered monoaminergic function, and shared genetic aetiology [1]. Both types of disorder are significantly more frequently diagnosed in males than in females, suggesting a potential role for sex-linked genetic risk variants [2], and both can have long-term adverse consequences for example, increased risk for alcohol dependence in ADHD [3] or lack of independence, close social ties and employment in ASDs [4].

Both cytogenetic deletions at Xp22.32 encompassing the X-linked STS gene (encoding the enzyme steroid sulphatase) and its immediate neighbours, and inactivating point mutations within STS, appear to predispose to ADHD (particularly the inattentive subtype) [5]; larger cytogenetic deletions encompassing STS and more distant contiguous genes (notably NLGN4X) seem to predispose to autism and related disorders [5]. Polymorphisms within STS are associated with ADHD risk [6,7] and cognitive function in individuals with ADHD [8], whilst the gene is expressed in regions of the developing brain whose structure is known to be altered in ADHD cases [8]. Steroid sulphatase cleaves sulphate groups from a variety of steroid hormones (for example, dehydroepiandrosterone sulphate, DHEAS) thereby altering their activity and/or specificity, and subsequent developmental and physiological effects [9]. As sulphated and non-sulphated steroid hormones can act as modulators at key neurotransmitter receptors, including N-methyl-D-aspartic acid (NMDA) and $\gamma$-aminobutyric acid type $\mathrm{A}\left(\mathrm{GABA}_{\mathrm{A}}\right)$ receptors [9], lack of STS developmentally could potentially elicit important effects on neuronal organisation processes mediated by these neurotransmitters [10].

Inactivating mutations within the ASMT gene, located within the pseudoautosomal region of the human $\mathrm{X}$ chromosome and encoding the enzyme acetylserotonin O-methyltransferase that catalyses the final step in melatonin biosynthesis, have been suggested as being potentially pathogenic in a variety of psychiatric and developmental conditions, including ASDs [11-17]. Such mutations may act to reduce systemic melatonin levels, a reported feature of individuals with ASDs [15]. Alternatively, or additionally, they could affect upstream substrate levels in the brain or blood platelets, for example, of the growth factor serotonin (5-hydroxytryptamine, 5-HT) or blood cell function [15]; elevated platelet serotonin levels are a consistent finding in ASD cases [18].

The $39, \mathrm{X}^{\mathrm{Y}^{*}} \mathrm{O}$ mouse lacks both the pseudoautosomal Sts and Asmt genes (and hence their expression in all tissues) as a consequence of an end-to-end fusion of the $\mathrm{X}$ and $\mathrm{Y}$ chromosomes [19]; as such, it has some degree of construct validity as a genetic mouse model for neurodevelopmental disorders. On an MF1 outbred albino strain background, this mouse also exhibits considerable face validity for such disorders: it is inattentive [20], hyperactive, emotionally hyper-reactive (showing increased indices of stress in novel or arousing environments), occasionally aggressive [21], and perseverative (showing persistent responding in the absence of reinforcement) $[19,22]$ and exhibits reduced systemic DHEA levels [21]. Whilst melatonin levels in wildtype and $39, \mathrm{X}^{\mathrm{Y}^{*} \mathrm{O}} \mathrm{MF} 1$ male mice remain to be determined, other outbred albino strains are known to produce significant quantities of the hormone [23].

Currently, the neurobiology of the $39, \mathrm{X}^{\mathrm{Y}^{*}} \mathrm{O}$ mouse is poorly defined, although we have previously shown that it exhibits altered monoaminergic chemistry, notably elevated hippocampal and striatal serotonin levels and reduced 5 -HT turnover in these regions $[19,22]$. Interestingly, however, the $39, \mathrm{X}^{\mathrm{Y}^{\prime \prime}} \mathrm{O}$ mouse, in contrast to individuals with ADHD, exhibits enhanced behavioural inhibition relative to $40, \mathrm{XY}$ male controls as indexed by performance on murine versions of the 5-choice Serial Reaction Time Task and the Stop Signal Reaction Time Task [20, S.T., O.A.O. and W.D., unpublished observations]. We have previously shown that acute administration of one dose of the specific steroid sulphatase inhibitor COUMATE to wildtype male mice also results in inattention [20] and enhanced behavioural inhibition [S.T., O.A.O. and W.D., unpublished observations], suggesting that these phenotypes in the $39, \mathrm{X}^{\mathrm{Y}^{* \prime}} \mathrm{O}$ mouse are due to the ongoing activity of the enzyme. Other phenotypes in the $39, \mathrm{X}^{\mathrm{Y}^{*}} \mathrm{O}$ mouse (for example, hyperactivity and anxiety) cannot be recapitulated by acute inhibition of steroid sulphatase [21], suggesting that they may arise from the developmental effects of deficiency for the enzyme, or alternatively from neuroendocrinological abnormalities as a consequence of ASMT deficiency.

Here, we further investigated the neurobiology of the $39, \mathrm{X}^{\mathrm{Y}^{\prime \prime}} \mathrm{O}$ mouse using two methods, with a view to identifying biological correlates of the behaviours mentioned above. First, we compared gene expression in adult 40, $\mathrm{XY}$ and $39, \mathrm{X}^{\mathrm{Y}^{*} \mathrm{O}}$ whole brain tissue by microarray to identify non-obvious genetic changes between the two groups, that is changes that could not be predicted $a$ priori on the basis of known biology; we assayed whole brain tissue given that Sts is widely expressed throughout the mouse brain, and because disruptions to multiple brain regions were likely to underpin the $39, \mathrm{X}^{\mathrm{Y}^{*}} \mathrm{O}$ behavioural phenotypes. We also tested to see whether any of the significant changes were seen in the $39, \mathrm{X}^{\mathrm{Y}^{*}} \mathrm{O}$ hippocampus or striatum (given the known changes in 5-HT levels), or in COUMATE-treated male mouse whole brain (and hence whether they could explain the effects of acute STS deficiency on attention and behavioural inhibition). Second, we characterised brain steroids in the adult 40,XY mouse for the first time, and 
compared this profile to that of the $39, \mathrm{X}^{\mathrm{Y}^{\prime \prime}} \mathrm{O}$ mouse. We anticipated that these combined approaches might reveal new pathophysiological mechanisms underlying phenotypes associated with STS/ASMT deficiency specifically and neurodevelopmental disorders more generally, and might highlight novel factors protecting against behavioural disinhibition. We report that $39, \mathrm{X}^{\mathrm{Y}^{\prime \prime}} \mathrm{O}$ mice show a highly specific pattern of gene expression changes, with several being of relevance to developmental disorders, but surprisingly, no large changes in brain steroid levels.

\section{Methods}

\section{Subjects}

All experimental research involving animals was performed in accordance with the Animal (Scientific Procedures) Act 1986 (United Kingdom) and was approved by the UK Home Office. 39, $\mathrm{X}^{\mathrm{Y}^{*} \mathrm{O}}$ and $40, \mathrm{XY}$ mice, matched for genetic background (predominantly MF1 strain), were bred and genotyped for the presence or absence of Sts at the Medical Research Council National Institute for Medical Research (MRC NIMR) as described previously [22]; at six weeks of age, behaviourally naïve, group-housed $40, \mathrm{XY}(\mathrm{n}=10)$ and $39, \mathrm{X}^{\mathrm{Y}^{\prime \prime}} \mathrm{O}(\mathrm{n}=10)$ mice were culled by cervical dislocation between 1200 and 1500 hours, and their brains frozen immediately at $-80^{\circ} \mathrm{C}$ for subsequent RNA extraction. Some $40, \mathrm{XY}$ and $39, \mathrm{X}^{\mathrm{Y}^{*} \mathrm{O}}$ mice were subsequently transferred to Cardiff University, where they were treated with antibiotics to treat a Pasteurella pneumotropica infection prior to release onto the open racks and behavioural testing; these mice were then culled by cervical dislocation between 1100 and 1300 hours (aged 10 to 12 months), and their hippocampi and striata dissected from the left hemisphere and frozen immediately at $-80^{\circ} \mathrm{C}$ ( $\mathrm{n}=6$ per group). For the pharmacological study, behaviourally naïve, six-week old, male MF1 mice (Harlan, UK) were administered 7-O-sulphamoyl-4methylcoumarin (COUMATE) at a dose previously shown to influence behaviour [20] $(10 \mathrm{mg} / \mathrm{kg}$ in $0.5 \%$ methylcellulose $0.9 \%$ saline vehicle, per os $(\mathrm{po}), \mathrm{n}=12$ ) or vehicle alone $(n=12) ; 24$ hours later they were culled by cervical dislocation between 1600 and 1830 hours, their brains dissected and immediately frozen at $-80^{\circ} \mathrm{C}$. For the brain steroid measurements, behaviourally-naïve, group-housed mice ( $\mathrm{n}=8$ per group) from MRC NIMR were culled by cervical dislocation between 1100 and 1500 hours (aged five to seven months), their brains dissected and frozen immediately at $-80^{\circ} \mathrm{C}$.

\section{RNA extraction and CDNA biosynthesis}

High quality total RNA (absorbance ratios of 1.7 to 2.1) for the microarray study was extracted from $40, \mathrm{XY}$ and $39, \mathrm{X}^{\mathrm{Y}^{*}} \mathrm{O}$ hemibrain tissue using RNeasy Lipid Tissue Kit (Qiagen, Manchester, UK), and DNase-treated using
RNase-free DNase kit (Qiagen, Manchester, UK). For other tissue samples, high quality RNA was extracted by homogenising the tissue in TRIReagent (Sigma-Aldrich, Gillingham, UK), precipitating with isopropanol, washing in $75 \%$ ethanol, and resuspending in RNase-free distilled water; DNase treatment was then carried out using the TURBO DNA-free kit (Life Technologies, Paisley, UK). cDNA was synthesised from 1 to $2 \mu \mathrm{g}$ RNA per sample using EcoDry Premix with random hexamers (Clontech, Mountain View, CA, USA), and diluted 25-fold.

\section{Microarray analysis}

Total RNA was supplied to Source Bioscience Ltd. (Nottingham, UK) where it underwent quality control checks prior to conversion to cRNA and hybridisation to the Mouse Gene 1.0 ST array (Affymetrix, Santa Clara, USA) according to their standard protocol. To reduce the possibility of spurious expression differences, we carried out four separate hybridisations: 40,XY1 (five pooled hemibrains), 40,XY2 (five pooled hemibrains), 39, $\mathrm{X}^{\mathrm{Y}^{*}} \mathrm{O} 1$ (five pooled hemibrains), and $39, \mathrm{X}^{\mathrm{Y}^{*} \mathrm{O}} 2$ (five pooled hemibrains). Array data were subject to normalisation using the Robust Multipoint Average (RMA) procedure (background adjustment, quantile normalisation and summarisation) within the Affymetrix Expression Console prior to being loaded in the CLC Bio Genomics Workbench to examine differential expression across samples. Microarray data are available via ArrayExpress [24] (accession number E-MEXP-3943).

\section{Quantitative polymerase chain (qPCR) analysis}

Quantitative PCR (qPCR) analysis of gene expression was performed using a Rotorgene 6000 coupled with a CAS1200 automated set-up, and utilizing standard consumables (Qiagen, Manchester, UK). PCR reactions were performed using $5 \mu \mathrm{l} \mathrm{cDNA}$ mix and $200 \mathrm{nM}$ customdesigned primers (Additional file 1) and Quantace SensiMix (Bioline, London, UK). qPCR data were analysed using $\Delta \mathrm{C}_{\mathrm{t}}$ methods as described previously [25]. Briefly, individual PCR reaction data were normalised to the mean of at least three 'housekeeping gene standards' (Hprt, Gapdh, Actb and $R n 18 s$, whose expression was significantly correlated within the samples), giving a value known as $\Delta C_{\mathrm{t}}$. The data were processed further to show how the $39, \mathrm{X}^{\mathrm{Y}^{*}} \mathrm{O}$ values vary with respect to those of the $40, \mathrm{XY}\left(\Delta \Delta C_{\mathrm{t}}\right)$ and allow simpler graphical representation after transformation $\left(2^{-\Delta \Delta C t}\right)$.

\section{Brain steroid analysis}

Pooled samples (40,XY: $\left.\mathrm{n}=4,39, \mathrm{X}^{\mathrm{Y}^{*}} \mathrm{O}: \mathrm{n}=4\right)$ were generated for each group (two whole brains per pool). Free steroids and their sulphate esters were extracted from brain tissue and fractionated prior to derivatisation with methoxyamine (MO) and trimethylsilylimidazole (TMSI) for gas chromatography-mass spectrometry (GC-MS) as 
previously described [26] except that steroid sulphates were deconjugated by incubation with Helix sulphatase rather than by solvolysis [27]. Briefly, after drying down and redissolving in sodium acetate $(0.5 \mathrm{M}, \mathrm{pH} 5.0)$, the sulphates were deconjugated by incubation with the arylsulphatase enzyme from Helix pomatia Type H1 (SigmaAldrich, Gillingham, UK) at $1 \mathrm{mg} / \mathrm{ml}$ overnight at $40^{\circ} \mathrm{C}$, then at $55^{\circ} \mathrm{C}$ for two hours. The deconjugated steroids could then be recovered by loading the incubate onto a $60 \mathrm{mg}$ hydrophobic-lipophilic balance (HLB) cartridge (Waters, Milford, MA, USA). After a wash with $5 \mathrm{ml}$ water, the steroids were eluted from this cartridge with 4 $\mathrm{ml}$ ethyl acetate. These steroids liberated by deconjugation of the sulphate fraction were then dried down under nitrogen and derivatised with MO and TMSI for GCMS alongside the steroids from the free steroid fraction of mouse brain. Increasing amounts (1.4 to $23.1 \mathrm{ng}$ ) of standard reference steroids were derivatised at the same time for calibration and each sample and calibration reference included a fixed amount (50 ng) of the internal

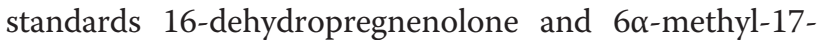
hydroxyprogesterone. Column conditions for the $\mathrm{GC}$ were as previously described, with elution of the MO-TMSsteroids detected by selective ion monitoring as follows: androsterone, 270 and 360; dehydroepiandrosterone, 268 and 358; epiandrosterone, 270 and 360; androstenediol, 129 and 239; 17ß-oestradiol, 129, 285 and 416; testosterone, 129 and 389; allopregnanolone, 298 and 388; 16-dehydropregnenolone, 400 and 415; allopregnanediol, 269 and 346; pregnenolone, 288 and 386; epiallopregnanolone, 243 and 388; $5 \alpha$-dihydroprogesterone, 288 and 343; 20 $\beta$-dihydropregnenolone, 372 and 462; $20 \alpha$-dihydropregnenolone, 372 and 462; progesterone, 341 and 372; $5 \alpha, 20 \alpha$-tetrahydroprogesterone, 289 and 303; 6 $\alpha$-methyl-17-hydroxyprogesterone, 443 and 474.

\section{Statistics}

For the microarray data, statistical significance of the changes in mean expression levels per group was examined by the unpaired two-tailed $t$-test with a single overall factor of KARYOTYPE (that is $40, \mathrm{XY}$ or $39, \mathrm{X}^{\mathrm{Y}^{*}} \mathrm{O}$ ) within CLC Bio Genomics Workbench; P-values taking into account correction for False Discovery Rate were also calculated. For the qPCR analyses, samples $>$ two standard deviations from the group mean were excluded as outliers; statistical significance of the changes in expression levels was examined using $2^{-\Delta \mathrm{Ct}}$ values by the unpaired $t$-test (normally distributed data according to ShapiroWilks test) or Mann-Whitney $U$-test (non-normally distributed data according to Shapiro-Wilks test) with a single factor of KARYOTYPE. Where variance within the two groups was unequal, Greenhouse-Geisser corrected degrees of freedom are indicated. Where the direction of effects could be predicted, that is in confirming microarray findings, a one-tailed test was used; in other cases, a twotailed test was used. For the brain steroid hormone analyses, data were tested for normality as above, and analysed by the unpaired $t$-test with a single factor of KARYOTYPE. $P$-values $\leq 0.05$ were regarded as significant, and all data are presented as mean values \pm standard error of the mean.

\section{Results}

\section{Microarray analysis}

Filtering for nominal $P$-values $<0.05$, and $>2$-fold change identified just 13 genes of interest in addition to Sts, which was, as expected, found to be significantly downregulated; of these genes, eight appeared to be upregulated, and five downregulated (Table 1). Asmt was not represented on the array. Just one gene, Erdr1 (NM_133362.1) survived correction for False Discovery Rate $(P=0.044)$. Of particular note was the finding that two genes that lie adjacent to one another on chromosome 11 (Sfi1 and Pisd-ps1) were both upregulated, a result highly unlikely to occur by chance. A further 1,536 transcripts (out of 26,166 RefSeq transcripts represented on the array) were potentially more subtly differentially expressed (that is $P<0.05$, but $<2$-fold expression change); of these, 47 had previously been implicated in autism and/ or ADHD according to relevant online databases [28-30]: Abat, Arhgap15, Cdh8, Chrna7, Cldn5, Cntn3, Crygc, Cttnbp2, Ctnna2, Dctn5, Dhcr7, Dhrs3, Ehmt1, Elovl6, Eif4e1b, Eln, Fbxo40, Gclc, Gdi1, Gfod1, Gpd2, Grid2, Hepacam, Hes1, Hes6, Irak1, Kcnj10, Lphn3, Lrp2, Lrrn3, Mcph1, Mctp1, Mid1, Nlgn1, Npy5r, Nucb1, Park2, Pdzd4, Plcb1, Prodh, Prrt2, Prune2, Scn2a1, Slc25a12, Srsf3, Syngap1 and Ythdc2.

\section{Confirmation of microarray results by quantitative PCR (qPCR)}

Initially, we sought to confirm microarray changes $>2$ fold and with a $P$-value $<0.05$ by qPCR using individual samples ( $\mathrm{n}=10$ per group). The direction of effect was consistent between the microarray and the qPCR analysis for 12 of the 13 genes in Table 1. However, the expression of only seven of the 13 genes was confirmed as being significantly different between the two experimental groups by qPCR (Figure 1A): six upregulated: Vmn2r86: $\mathrm{t}_{8.00}=-6.11, P<0.001$ (expression higher than $40, \mathrm{XY}$ mean in $10 / 1039, \mathrm{X}^{\mathrm{Y}^{*}} \mathrm{O}$ samples), Sfi1: $\mathrm{t}_{16}=-8.62$, $P<0.001$ (expression higher than 40,XY mean in $10 / 10$ 39, $\mathrm{X}^{\mathrm{Y}^{*}} \mathrm{O}$ samples), Pisd-ps1: $\mathrm{t}_{11.84}=-1.84, P<0.05$ (expression higher than 40,XY mean in $7 / 1039, \mathrm{X}^{\mathrm{Y}^{*}} \mathrm{O}$ samples), Tagap1: $\mathrm{t}_{17}=-3.32, P<0.005$ (expression higher than $40, \mathrm{XY}$ mean in $8 / 1039, \mathrm{X}^{\mathrm{Y}^{*} \mathrm{O}}$ samples), C1qc: $t_{9.07}=-11.47, P<0.001$ (expression higher than 40,XY mean in $10 / 1039, \mathrm{X}^{\mathrm{Y}^{*}} \mathrm{O}$ samples), Metap1d: $\mathrm{t}_{9.29}=-12.02, P<0.001$ (expression higher than $40, \mathrm{XY}$ 
Table 1 Genes showing $>2$ fold change at $P<0.05$ in $39, \mathrm{X}^{\mathrm{Y}^{*}} \mathrm{O}$ whole brain based on the microarray analysis

\begin{tabular}{|c|c|c|c|c|c|}
\hline \multicolumn{6}{|c|}{ Upregulated in $39, \mathrm{X}^{Y^{*}} \mathrm{O}$ brain } \\
\hline Gene & Chromosome & Product & Fold change & $P$-value & Human orthologue \\
\hline Gm16432 & 1 & Function unknown & 5.5 & 0.006 & None \\
\hline Vmn2r86 & 10 & Vomeronasal 2 receptor 86 & 3.6 & 0.03 & None \\
\hline Sfil & 11 & Sfi1 homolog, spindle assembly associated (yeast) & 3.3 & 0.007 & SFI1 (22q12.2) \\
\hline Pisd-ps 1 & 11 & Phosphatidylserine decarboxylase, pseudogene 1 & 2.7 & 0.02 & None \\
\hline Tagap 1 & 17 & T cell activation GTPase activating protein 1 & 2.4 & 0.01 & None \\
\hline $\mathrm{Clac}$ & 4 & Complement component 1, q subcomponent, $\mathrm{C}$ chain & 2.3 & 0.002 & C1QC (1p36.11) \\
\hline Fam177a & 12 & Family with sequence similarity 177, member $A$ & 2.2 & 0.004 & FAM177A1 (14q13.2) \\
\hline Metap1d & 2 & Methionyl aminopeptidase type 1D & 2.0 & 0.0003 & METAP1D (2q31.1) \\
\hline \multicolumn{6}{|c|}{ Downregulated in $39, \mathrm{X}^{\mathrm{Y}^{*}} \mathrm{O}$ brain } \\
\hline Gene & Chromosome & Product & Fold change & p-value & Human orthologue \\
\hline Erdr1 & Y & Erythroid differentiation regulator 1 & 3.6 & $1.3 \times 10^{-6}$ & None \\
\hline Trdn & 10 & Triadin & 3.1 & 0.03 & $\operatorname{TRDN}(6 \mathrm{q} 22.31)$ \\
\hline Gm12696 & 4 & Pseudogenic RNA & 2.9 & 0.01 & None \\
\hline Fut11 & 14 & Fucosyltransferase 11 & 2.2 & 0.002 & FUT11 (10q22.2) \\
\hline AA388235 & 17 & Non-coding RNA & 2.1 & 0.03 & None \\
\hline
\end{tabular}

mean in 10/10 39, $\mathrm{X}^{\mathrm{Y}^{*}} \mathrm{O}$ samples), and one downregulated: Erdr1: $\mathrm{t}_{9.00}=5.96, P<0.001$ (expression lower than 40,XY mean in $10 / 1039, \mathrm{X}^{\mathrm{Y}^{*}} \mathrm{O}$ samples). Prima facie, these genes do not appear to function within common known pathways, being involved in signal transduction (Vmn2r86), phosphatase activity regulation (Sfi1), complement activation in the immune response $(C 1 q c)$, mitochondrial proteolysis (Metapld) and regulation of cell proliferation and migration (Erdr1) [31]. The expression of Fam177a showed a trend towards being more highly expressed in $39, \mathrm{X}^{\mathrm{Y}^{*}} \mathrm{O}$ brain than $40, \mathrm{XY}$ brain $\left(\mathrm{t}_{17}=-1.51, P=0.08\right)$. The expression of the Gm16432, Trdn, Gm12696, Fut11 and $A A 388235$ genes did not differ significantly as a function of KARYOTYPE $\left(\mathrm{t}_{18}=-0.67, P=0.26, \mathrm{t}_{18}=0.45, P=\right.$
0.33, $\mathrm{t}_{18}=-0.18, P=0.43, \mathrm{t}_{17}=1.08, P=0.15$ and $P=$ 0.94 respectively).

The Erdr1 gene is located adjacent to the fusion point of the $\mathrm{X}$ and $\mathrm{Y}$ chromosomes in the $39, \mathrm{X}^{\mathrm{Y}^{*}} \mathrm{O}$ mouse; therefore we tested whether two additional genes not represented on the microarray, which lie directly adjacent to Erdr1 (G530011O06Rik and LOC100861696) [19] were also differentially expressed in $39, \mathrm{X}^{\mathrm{Y}^{*} \mathrm{O}}$ and $40, \mathrm{XY}$ brain; this did not appear to be the case: G530011006Rik: $\mathrm{t}_{13.4}=-0.037, P=0.97$, LOC100861696: $P=0.33$ (see Additional file 2).

Subsequently, we examined the expression of a selection of genes with known, or suspected, roles in neurodevelopmental disorders with $<2$-fold change $(1.04$ to
A

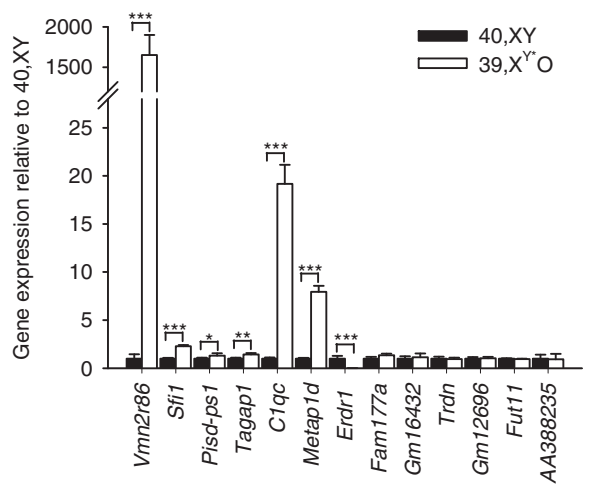

B

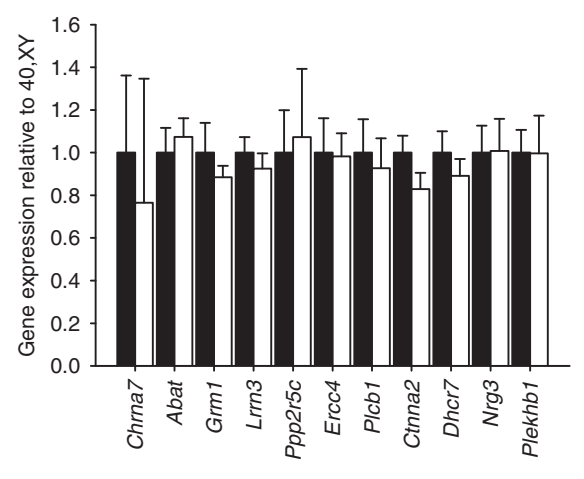

Figure 1 Gene expression in $40, \mathrm{XY}$ and $39, \mathrm{X}^{\mathrm{Y}^{*}} \mathrm{O}$ adult hemibrain tissue. Of the thirteen microarray calls showing $>2$-fold change with $P$-values $<0.05$, seven were confirmed by quantitative PCR (A). Of 11 genes previously implicated in neurodevelopmental phenotypes, and having microarray calls with $P$-values $<0.05$, none were found to be significantly differentially expressed between the two experimental groups (B). ${ }^{*} P<0.05,{ }^{* *} P<0.01,{ }^{* * *} P<0.001$. 
1.25 -fold change) but $P$-values $<0.05$ using qPCR. Of the 11 genes examined, none were confirmed as being significantly differentially expressed between 40,XY and $39, \mathrm{X}^{\mathrm{Y}^{*}} \mathrm{O}$ groups (Figure 1B, Chrna7: $\mathrm{t}_{17}=-0.15$, $P=0.44$, Abat: $P=0.33$, Grm1: $\mathrm{t}_{17}=1.26, P=0.12$, Lrrn3: $\mathrm{t}_{18}=0.77, P=0.23, \operatorname{Ppp} 2 r 5 c: \mathrm{t}_{17}=-0.62, P=$ 0.28, Ercc4: $\mathrm{t}_{18}=0.32, P=0.38, P l c b 1: \mathrm{t}_{16}=0.41, P=0.34$, Ctnna2: $\mathrm{t}_{17}=1.71, P=0.06$, Dhcr7: $\mathrm{t}_{18}=1.04, P=0.16$, Nrg3: $\mathrm{t}_{18}=-0.15, P=0.45$, Plekhb1 $\left.\mathrm{t}_{18}=-0.27, P=0.40\right)$.

\section{Gene expression changes in the hippocampus and} striatum of $39, \mathrm{X}^{\mathrm{Y}^{*}} \mathrm{O}$ mice

Of the seven genes whose expression levels differed in $40, \mathrm{XY}$ and $39, \mathrm{X}^{\mathrm{Y}^{*}} \mathrm{O}$ whole brain tissue, six were expressed in the adult hippocampus, and all showed reduced mean levels in $39, \mathrm{X}^{\mathrm{Y}^{*}} \mathrm{O}$ tissue (Figure 2A). However, for only two of these (Erdr1 and $C 1 q c)$, was this reduction statistically significant: Sfi1: $\mathrm{t}_{10}=1.81$, $P=0.10$, Pisd-ps1: $\mathrm{t}_{10}=1.20, P=0.26$, Tagap $1: \mathrm{t}_{10}=$ 0.78, $P=0.45$, Metap1d: $\mathrm{t}_{10}=1.04, P=0.33$, Erdr1: $\mathrm{t}_{5.00}=3.17, P=0.025$ (expression lower than 40,XY mean in $6 / 639, \mathrm{X}^{\mathrm{Y}^{*}} \mathrm{O}$ samples), C1qc: $P=0.004$ (expression lower than $40, \mathrm{XY}$ mean in $6 / 639, \mathrm{X}^{\mathrm{Y}^{*}} \mathrm{O}$ samples)). We also examined hippocampal expression of $\mathrm{Dhcr} 7$ (encoding 7 -dehydrocholesterol reductase, $P<0.05$ in the microarray analysis) given that this gene had previously been implicated in neurodevelopmental disorders, and that its deficiency had been implicated in altered serotonergic function [32]. We found that in $39, \mathrm{X}^{\mathrm{Y}^{*}} \mathrm{O}$ hippocampus, Dhcr 7 expression was significantly downregulated relative to 40,XY expression: $t_{5.97}=3.47, P=0.013$ (expression lower than $40, \mathrm{XY}$ mean in $6 / 639, \mathrm{X}^{\mathrm{Y}^{*} \mathrm{O}}$ samples) (Figure 2A).

Of the seven genes whose expression levels differed in $40, \mathrm{XY}$ and $39, \mathrm{X}^{\mathrm{Y}^{*}} \mathrm{O}$ whole brain tissue, six were expressed in the adult striatum; we also examined
Dhcr7 expression in this tissue. Both Erdr1 and C1qc genes were found to be significantly downregulated in $39, \mathrm{X}^{\mathrm{Y}^{*}} \mathrm{O}$ striatum: $\mathrm{t}_{5.19}=3.12, P=0.025$ and $\mathrm{t}_{10}=8.69$, $P<0.001$ respectively (expression lower than $40, \mathrm{XY}$ mean in $6 / 639, \mathrm{X}^{\mathrm{Y}^{*}} \mathrm{O}$ samples for both genes). The expression of the remaining five genes was equivalent in 40, $\mathrm{XY}$ and $39, \mathrm{X}^{\mathrm{Y}^{*} \mathrm{O}}$ striatum (Figure 2B, Sfi1: $\mathrm{t}_{10}=1.35, P=$ 0.21, Pisd-ps1: $\mathrm{t}_{10}=-0.58, P=0.58$, Tagap1: $\mathrm{t}_{6.59}=$ 1.29, $P=0.24$, Metap1d: $\mathrm{t}_{10}=1.04, P=0.32$, Dhcr7: $\left.\mathrm{t}_{10}=0.33, P=0.75\right)$.

\section{Brain gene expression changes in wildtype COUMATE-treated male mice}

To determine whether the behavioural effects arising from acute steroid sulphatase inhibition could be due to altered expression of the Vmn2r86, Sfi1, Pisd-ps1, Tagap1, C1qc, or Map1d genes, we compared their expression in COUMATE and vehicle-treated MF1 male hemibrain. Erdr1 expression was not examined in COUMATE-treated brain given that its reduced expression in the $39, \mathrm{X}^{\mathrm{Y}^{*}} \mathrm{O}$ brain was due to a direct effect of the genetic mutation and not a downstream effect of Sts or Asmt deficiency. None of the six genes assayed were significantly differentially expressed in these tissues: Vmn2r86 $\left(\mathrm{t}_{22}=-0.99, P=0.33\right)$, Sfi1 $\left(\mathrm{t}_{21}=0.01, P=\right.$ 0.99), Pisd-ps1 ( $\left.\mathrm{t}_{20}=0.84, P=0.41\right)$, Tagap1 $\left(\mathrm{t}_{22}=-0.82\right.$, $P=0.42), C 1 q c\left(\mathrm{t}_{22}=-0.42, P=0.68\right)$, Metap1d $\left(\mathrm{t}_{21}=\right.$ $0.64, P=0.53$ ) (Additional file 3 ).

\section{Steroid hormone analysis}

Of the 15 steroids whose identity could reliably be determined from their elution and ion profile in our GC-MS analyses, ten had concentrations above the limit of detection in the free steroid fraction: (dehydroepiandrosterone (DHEA), epiandrosterone, testosterone, allopregnanolone, pregnenolone, epiallopregnanolone, $5 \alpha$-dihydroprogesterone,
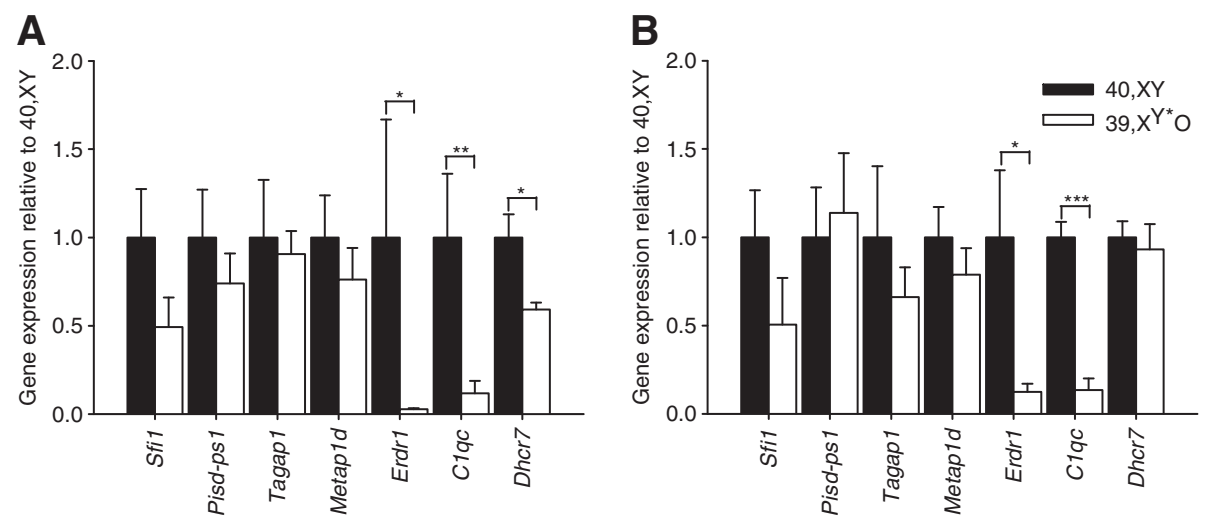

Figure 2 Gene expression in $40, X Y$ and $39, X^{Y^{*}} \mathrm{O}$ adult brain regions. Of six candidate genes confirmed as being differentially expressed by microarray and known to be expressed in the hippocampus, two were significantly downregulated in this brain region in $39, X^{\Upsilon^{*}} \mathrm{O}$ mice (Erdr 1 and (1qc); a third gene, Dhcr7, implicated in serotonergic neurodevelopmental phenotypes, was also downregulated in mutant mice (A). Erdr1 and C1qc were also significantly downregulated in the $39, X^{Y^{*}}$ O striatum (B).* $P<0.05,{ }^{* *} P<0.01,{ }^{* *} P<0.001$. 
$20 \alpha$-dihydropregnenolone, progesterone and $5 \alpha, 20 \alpha$ tetrahydroprogesterone). The concentrations of these ten steroids did not differ significantly between 40,XY and $39, \mathrm{X}^{\mathrm{Y}^{*}} \mathrm{O}$ brains, although there was considerable intra-group variability, particularly in the mutant group (Table 2).

In the steroid sulphate fraction, two steroids had concentrations above the limit of detection (DHEAS and epiandrosterone sulphate); the concentrations of both of these steroids did not differ significantly in 40,XY and $39, \mathrm{X}^{\mathrm{Y}^{*}} \mathrm{O}$ brain (Table 2).

\section{Discussion}

The $39, \mathrm{X}^{\mathrm{Y}^{*}} \mathrm{O}$ mouse model exhibits face and construct validity for neurodevelopmental disorders, showing behavioural endophenotypes associated with such conditions, and lacking two genes (Sts and Asmt) whose human orthologues have been implicated in ADHD and autism pathogenesis respectively. In this study, we investigated the neurobiology of this model by two methods with a view to identifying mechanisms by which loss of function of these genes might contribute towards behavioural pathology; this work is important given the current lack of availability of single gene knockout models for Sts and Asmt.

Microarray and quantitative PCR analyses comparing $40, \mathrm{XY}$ and $39, \mathrm{X}^{\mathrm{Y}^{*}} \mathrm{O}$ brain tissue identified a surprisingly small number of robust gene expression differences between the groups. Our inability to verify differential microarray expression calls at $P<0.05$ for multiple transcripts of relevance to autism and ADHD suggests that we are likely to have successfully identified all the genes that truly differ in their expression across the whole brain in 40,XY and $39, \mathrm{X}^{\mathrm{Y}^{* *}} \mathrm{O}$ mice. However, it is possible that there are further group differences in gene expression within specific brain regions; indeed, our

Table 2 Levels of free and sulphated steroids in whole adult $40, X Y$ and $39, X^{Y^{*}} O$ mouse brain ( $n=4$ per group)

\begin{tabular}{|c|c|c|c|c|c|c|}
\hline \multirow{2}{*}{$\begin{array}{c}\text { Steroid } \\
\text { (systematic name in brackets) }\end{array}$} & \multicolumn{3}{|c|}{ Free steroids } & \multicolumn{3}{|c|}{ Steroid sulphates } \\
\hline & $\begin{array}{c}40, X Y \\
\text { Concentration } \\
(n g / g)\end{array}$ & $\begin{array}{c}39, \mathrm{X}^{\mathrm{Y}^{*}} \mathrm{O} \\
\text { Concentration } \\
(\mathrm{ng} / \mathrm{g})\end{array}$ & Significance $t_{6}$ & $\begin{array}{c}40, X Y \\
\text { Concentration } \\
(n g / g)\end{array}$ & $\begin{array}{c}39, \mathrm{X}^{\mathrm{Y}^{*} \mathrm{O}} \\
\text { Concentration } \\
(\mathrm{ng} / \mathrm{g})\end{array}$ & Significance $t_{6}$ \\
\hline $\begin{array}{c}\text { Androsterone } \\
\text { (5a-androstan-3a-ol-17-one) }\end{array}$ & $N D_{;}<4.56$ & $\mathrm{ND} ;<4.56$ & N/A & $N D_{i}<0.63$ & $\mathrm{ND} ;<0.63$ & N/A \\
\hline $\begin{array}{l}\text { dehydroepiandrosterone } \\
\text { (5-androsten-3ß-ol-17-one) }\end{array}$ & $36.15 \pm 9.74$ & $32.91 \pm 15.21$ & $0.18, P=0.86$ & $0.51 \pm 0.02$ & $0.53 \pm 0.01$ & $-1.34, P=0.23$ \\
\hline $\begin{array}{c}\text { Epiandrosterone } \\
\text { (5a-androstan-3 } \beta-o l-17-o n e)\end{array}$ & $2.80 \pm 0.12$ & $3.60 \pm 0.44$ & $-1.77, P=0.13$ & $0.71 \pm 0.02$ & $0.72 \pm 0.01$ & $-0.66, P=0.54$ \\
\hline $\begin{array}{c}\text { Androstenediol } \\
\text { (5-androsten-3 } \beta, 17 \beta \text {-diol) }\end{array}$ & $N D_{;}<0.01$ & $N D_{i}<0.01$ & N/A & $N D_{i}<0.45$ & $N D_{i}<0.45$ & N/A \\
\hline $\begin{array}{c}17 \beta \text {-oestradiol } \\
(1,3,5(10) \text {-oestratrien-3,17 } \beta \text {-diol) }\end{array}$ & $N D_{i}<0.53$ & $N D_{i}<0.53$ & N/A & $N D_{i}<0.05$ & $N D ;<0.05$ & N/A \\
\hline $\begin{array}{c}\text { Testosterone } \\
\text { (4-androsten-17ß-ol-3-one) }\end{array}$ & $19.64 \pm 2.27$ & $19.63 \pm 9.81$ & $0.00, P=1.00$ & $N D_{i}<1.77$ & $N D_{i}<1.77$ & N/A \\
\hline $\begin{array}{c}\text { Allopregnanolone } \\
\text { (5a-pregnan-3a-ol-20-one) }\end{array}$ & $1.47 \pm 0.27$ & $1.95 \pm 0.77$ & $-0.59, P=0.58$ & $N D_{i}<0.01$ & $N D ;<0.01$ & N/A \\
\hline $\begin{array}{c}\text { Allopregnanediol } \\
\text { (5a-pregnan-3a,20a-diol) }\end{array}$ & $N D_{;}<0.01$ & $N D_{i}<0.01$ & N/A & $N D_{i}<0.01$ & $N D_{i}<0.01$ & N/A \\
\hline $\begin{array}{c}\text { Pregnenolone } \\
\text { (5-pregnen-3ß-ol-20-one) }\end{array}$ & $31.26 \pm 13.37$ & $25.12 \pm 15.05$ & $0.31, P=0.77$ & $N D_{i}<0.01$ & $N D_{i}<0.01$ & N/A \\
\hline $\begin{array}{c}\text { Epiallopregnanolone } \\
\text { (5a-pregnan-3 } \beta \text {-ol-20-one) }\end{array}$ & $17.07 \pm 5.13$ & $25.25 \pm 17.19$ & $-0.46, P=0.67$ & $N D_{i}<0.37$ & $\mathrm{ND} ;<0.37$ & N/A \\
\hline $\begin{array}{l}\text { 5a-dihydroprogesterone } \\
\text { (5a-pregnan-3,20-dione) }\end{array}$ & $12.75 \pm 5.26$ & $15.01 \pm 6.16$ & $-0.28, P=0.79$ & $N D_{i}<0.01$ & $N D ;<0.01$ & N/A \\
\hline 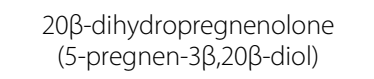 & $N D_{;}<3.10$ & $N D_{i}<3.10$ & N/A & $N D_{i}<0.01$ & $N D_{i}<0.01$ & N/A \\
\hline $\begin{array}{l}\text { 20a-dihydropregnenolone } \\
\text { (5-pregnen-3ß,20a-diol) }\end{array}$ & $0.91 \pm 0.11$ & $0.94 \pm 0.09$ & $-0.21, P=0.84$ & $N D_{i}<0.01$ & $N D_{;}<0.01$ & N/A \\
\hline $\begin{array}{c}\text { Progesterone } \\
\text { (4-pregnen-3,20-dione) }\end{array}$ & $3.74 \pm 0.34$ & $5.84 \pm 2.05$ & $-1.01, P=0.35$ & $N D_{i}<4.41$ & $N D_{;}<4.41$ & N/A \\
\hline $\begin{array}{l}\text { 5a,20a-tetrahydroprogesterone } \\
\text { (5a-pregnan-20a-ol-3-one) }\end{array}$ & $3.71 \pm 0.22$ & $3.97 \pm 0.48$ & $-0.50, P=0.64$ & $N D_{i}<1.61$ & $N D_{i}<1.61$ & N/A \\
\hline
\end{tabular}

N/A not applicable, ND not detectable. 
microarray analysis did not indicate altered expression of Htr2c (encoding the serotonin 2c receptor) which we have previously shown to be upregulated in the $39, \mathrm{X}^{\mathrm{Y}^{\prime \prime}} \mathrm{O}$ hippocampus [22].

Erdr1 gene expression was significantly reduced in 39, $\mathrm{X}^{\mathrm{Y}^{*} \mathrm{O}}$ whole brain, and in hippocampal and striatal dissections; this gene is retained in the $39, \mathrm{X}^{\mathrm{Y}^{*}} \mathrm{O}$ mouse and is located adjacent to the fusion point of the $\mathrm{X}$ and $\mathrm{Y}$ chromosomes [19]. Our current results suggest that in addition to deleting of the Sts and Asmt genes, the lesion in $39, \mathrm{X}^{\mathrm{Y}^{*}} \mathrm{O}$ mice disrupts a genetic element that enhances Erdr1 expression. Theoretically, in concert with loss of Sts and Asmt, reduced expression of the widely-expressed, but poorly-characterised, erythroid differentiation regulator 1 protein encoded by Erdr1 could contribute towards downstream gene expression changes, abnormal striatal and hippocampal monoamine neurochemistry, and behavioural phenotypes in the $39, \mathrm{X}^{\mathrm{Y}^{* \prime}} \mathrm{O}$ model; brain and behavioural investigations in mice in which the function of this gene alone is disrupted will help clarify the extent and specificity of this contribution.

Our microarray and qPCR analyses also showed that the expression of C1qc (encoding the protein complement component 1 , q subcomponent, c chain) was upregulated in the brains of young, behaviourally-naïve $39, \mathrm{X}^{\mathrm{Y}^{*}} \mathrm{O}$ mice, but downregulated in the striata and hippocampi of older, behaviourally-trained mutant animals. These data suggest a potential basis for the neurochemical and behavioural abnormalities seen in the $39, \mathrm{X}^{\mathrm{Y}^{\prime \prime}} \mathrm{O}$ mouse that may be sensitive to spatiotemporal or environmental regulation, and further suggest the possibility that the neurobehavioural pathology in individuals lacking functional STS and/or ASMT proteins may be due, in part, to altered $\mathrm{C} 1 \mathrm{QC}$ levels. Previous animal and clinical studies have implicated aberrant expression of $\mathrm{C} 1 \mathrm{q}$ family members in developmental and behavioural phenotypes. In rodents, $\mathrm{C} 1 \mathrm{q}$ deletion results in altered synaptic elimination [33,34], C1qc expression levels are altered in a model of developmental hippocampal pathology [35], and C1qc expression is associated with behavioural phenotypes (notably the consumption of ethanol relative to water) [36]. In man, individuals with autism can exhibit elevated C1QC serum levels [37] and altered gastrointestinal $\mathrm{C} 1 \mathrm{q}$ deposition $[38,39]$. Whether the $39, \mathrm{X}^{\mathrm{Y}^{\prime \prime}} \mathrm{O}$ mouse exhibits alterations in synaptic structure/function or hippocampal structure, or heightened alcohol preference remains to be investigated. It also remains to be seen whether individuals with elevated C1QC levels and autism possess genetic mutations in either STS or $A S M T$, and whether individuals lacking functional STS and/or ASMT genes are at increased risk of alcohol dependence.
By the same logic, the present findings further indicate that disrupted expression of Metap1d and/or Sfil could play a role in $39, \mathrm{X}^{\mathrm{Y}^{*}} \mathrm{O}$ phenotypes, and in developmental phenotypes associated with Xp22.3 mutations, but probably not through influencing striatal or hippocampal physiology. There is some evidence for an association between a linkage block at 2q31.1 containing METAP1D and autism [40], whilst copy number variants encompassing SFI1 have previously been identified in autism and related developmental disorders [41-45].

We also showed that the genetic mutation in $39, \mathrm{X}^{\mathrm{Y}^{*}} \mathrm{O}$ mice resulted in reduced hippocampal expression of the $D h c r 7$ gene. DHCR7 is a known modulator of serotonergic system development in mammals [32]; therefore, its reduced expression represents a strong candidate mechanism for abnormal serotonin levels in the $39, \mathrm{X}^{\mathrm{Y}^{\prime \prime}} \mathrm{O}$ hippocampus and associated behavioural phenotypes $[19,22]$. In man, defects in the DHCR7 enzyme underlie Smith-Lemli-Opitz syndrome (SLOS). Individuals with SLOS exhibit a range of behavioural symptoms with some overlap with autism, including: hyperactivity, aggression, insomnia, self-injurious behaviour, sensory hypersensitivity and repetitive behaviours [32]; interestingly, several of these behavioural abnormalities are also observed in the $39, \mathrm{X}^{\mathrm{Y}^{*}} \mathrm{O}$ mouse $[19,21,22]$, indicating that hippocampal loss of DHCR7 function may underlie key SLOS phenotypes, and suggesting the $39, \mathrm{X}^{\mathrm{Y}^{*}} \mathrm{O}$ mouse as a potential novel model for aspects of the syndrome.

Genetic and functional work in mice has indicated a link between steroid sulphatase and aggressive behaviour $[46,47]$. Consistent with this, $39, \mathrm{X}^{\mathrm{Y}^{\prime \prime}} \mathrm{O}$ mice [21], and mice co-administered COUMATE and DHEAS [48], exhibit elevated levels of aggression. Previous rodent studies have demonstrated that major urinary proteins may elicit aggressive behaviour through their actions at sensory neurons expressing Vmn2r putative pheromone receptors [49]. Of the 124 genes within the Vmn2r family, the expression of just one, Vmn2r86, was significantly altered in $39, \mathrm{X}^{\mathrm{Y}^{*}} \mathrm{O}$ brain; this increased expression thus represents an excellent candidate mechanism underlying aggression in these mutant mice. The fact that there is no human orthologue of Vmn2r86 may explain why individuals with $\mathrm{Xp} 22.3$ deletions encompassing STS and/ or ASMT do not consistently show obvious aggressive tendencies.

Acute administration of COUMATE, a specific steroid sulphatase inhibitor, given at a dose known to induce behavioural changes, did not recapitulate any of the whole brain gene expression changes seen in the $39, \mathrm{X}^{\mathrm{Y}^{*}} \mathrm{O}$ mouse. There are two obvious possibilities why this might be the case: i) the expression changes in the 39, $\mathrm{X}^{\mathrm{Y}^{*} \mathrm{O}}$ mouse result from abnormal developmental expression of STS and/or ii) the gene expression changes in the $39, \mathrm{X}^{\mathrm{Y}^{*}} \mathrm{O}$ mouse are the result of loss of function of 
ASMT, or reduced expression of Erdr1. A previous study found no effect of acute administration of COUMATE on the concentrations of endogenous DHEAS or DHEA in whole mouse brain, although the drug did reduce entry of systemic DHEAS into the brain [50]. Thus, the molecular basis of COUMATE-induced behavioural changes remains obscure; it is plausible that the drug induces brain regionspecific gene expression changes that we were unable to detect, and this possibility remains to be investigated.

Our current analyses provide, for the first time, a systematic profile of the steroid milieu in the mouse brain. There was substantial overlap between the free and sulphated steroids that were detectable in the adult male mouse brain (present data), and those that were most readily detectable in the adult male rat brain [26] consistent with a degree of cross-species homology, although, interestingly, concentrations of most compounds tended to be higher in mouse brain. We found no significant differences in the concentrations of the detectable compounds between $40, \mathrm{XY}$ and $39, \mathrm{X}^{\mathrm{Y}^{*}} \mathrm{O}$ brains, consistent with an absence of large between-group differences in steroid brain biochemistry. This finding, taken together with our previous data showing reduced serum DHEA levels in $39, \mathrm{X}^{\mathrm{Y}^{*}} \mathrm{O}$ mice [19] suggests the possibility that where STS is absent developmentally, as in $39, \mathrm{X}^{\mathrm{Y}^{*}} \mathrm{O}$ mice, a compensatory mechanism is recruited to cleave sulphated steroid esters in brain, but not in peripheral tissues. Due to the difficulty of generating $39, \mathrm{X}^{\mathrm{Y}^{*} \mathrm{O}}$ mice and precisely genetically-matched controls, and the apparent variability in brain steroid levels in the mutant group, our study had limited power, with several steroids below the limit of detection. As such, we cannot completely exclude the possibility that there are subtle differences in levels of one or more steroids within $40, \mathrm{XY}$ and $39, \mathrm{X}^{\mathrm{Y}^{* \prime}} \mathrm{O}$ brain tissue.

\section{Conclusions}

Here, we have shown that the genetic mutation in $39, \mathrm{X}^{\mathrm{Y}^{*}} \mathrm{O}$ mice, in addition to deleting the Sts and Asmt genes, also results in significant downregulation of the adjacent Erdr1 gene. In the absence of Sts or Asmt single gene knockout mice, the present study gives the first clues as to possible downstream gene expression changes that might result from the loss of one (or both) of these genes; of the limited number of robust resultant gene expression changes, several may be pertinent to $39, \mathrm{X}^{\mathrm{Y}^{* \prime}} \mathrm{O}$ neurochemical and behavioural phenotypes, and hence, to similar phenotypes in individuals with loss of function mutations within STS or ASMT. Importantly, it should be noted that just because gene expression differences across genotypes are large, they might not necessarily be biologically significant.

Future functional validation and pathway analysis studies in the $39, \mathrm{X}^{\mathrm{Y}^{*}} \mathrm{O}$ mouse throughout development, incorporating an examination of the spatiotemporal dynamics of protein changes indicated by our present study, should further elucidate the neurobiological pathways by which the $39, \mathrm{X}^{\mathrm{Y}^{* *}} \mathrm{O}$ mutation gives rise to behavioural phenotypes analogous to those seen in neurodevelopmental disorders. Future work might examine whether the gene expression changes seen here are recapitulated in accessible tissues from individuals lacking STS and/or ASMT, and could test for abnormalities in complement pathway function, mitochondrial metabolism and cholesterol biosynthesis. Should this be the case, these physiological abnormalities could modulate either the risk of developing ADHD or autism, and/or to the clinical course of these disorders.

Our analyses indicated no large differences in brain steroid concentration between $40, \mathrm{XY}$ and $39, \mathrm{X}^{\mathrm{Y}^{*}} \mathrm{O}$ adult mice, and hence, suggest that altered steroid biochemistry may not be a significant contributor to abnormal brain and behavioural phenotypes in this mouse model, nor to similar phenotypes in individuals with mutations in STS and/or ASMT. However, a developmental difference in brain steroid levels between Sts/Asmt-deficient and wildtype subjects may plausibly exist and contribute towards between-group adult behavioural phenotypes.

\section{Additional files}

\section{Additional file 1: Primer sequences for quantitative PCR analyses. Additional file 2: Expression of genes adjacent to Erdr1 in 40,XY and $39, \mathrm{X}^{\mathrm{Y}^{*}} \mathrm{O}$ hemibrain tissue. \\ Additional file 3: Comparison of gene expression in vehicle and COUMATE-treated $40, \mathrm{XY}$ mouse brain.}

\section{Abbreviations}

ADHD: Attention Deficit Hyperactivity Disorder; ASDs: autism spectrum disorders; DHEA(S): dehydroepiandrosterone (sulphate); GABA: $\gamma$-aminobutyric acid; GC-MS: gas chromatography-mass spectrometry; HLB: hydrophobic-lipophilic balance; 5-HT: 5-hydroxytryptamine; MO: methoxyamine; MRC NIMR: Medical Research Council National Institute for Medical Research; NMDA: N-acetyl-Daspartic acid; PCR: polymerase chain reaction; po: per os; qPCR: quantitative polymerase chain reaction; RMA: Robust Multipoint Average; SLOS: Smith-LemliOpitz syndrome; STS: steroid sulphatase; TMSI: trimethylsilylimidazole.

\section{Competing interests}

The authors declare that they have no competing interests.

\section{Authors' contributions}

ST, JPF and WD conceived and designed the experiments. ST, JPF and OAO performed the experiments. ST, JPF and WD analysed the data. ST, JFP, OAO and WD wrote the paper. All authors read and approved the final manuscript.

\section{Acknowledgments}

The work was supported by a Medical Research Council United Kingdom (MRC UK) New Investigator Research Grant to WD (G0900636), by a Research Councils UK Fellowship to WD, and by MRC UK funding to OAO (U117532009). The funding bodies had no role in the design, collection, analysis or interpretation of data, nor in the writing of the manuscript, nor in the decision to submit the manuscript for publication. COUMATE was a kind gift to JPF from Dr Laurent Nicolas. 


\section{Author details}

${ }^{1}$ Neuroscience and Mental Health Research Institute, Cardiff University, Cardiff, UK. ²Department of Neuroscience, Physiology and Pharmacology, University College London, London, UK. ${ }^{3}$ Medical Research Council National Institute for Medical Research, London, UK. ${ }^{4}$ Medical Research Council Centre for Neuropsychiatric Genetics and Genomics, Cardiff University, Cardiff, UK. ${ }^{5}$ School of Psychology, Cardiff University, Tower Building, Park Place, Cardiff CF10 3AT, UK.

Received: 17 October 2013 Accepted: 19 February 2014

Published: 6 March 2014

\section{References}

1. Rommelse NN, Geurts HM, Franke B, Buitelaar JK, Hartman CA: A review on cognitive and brain endophenotypes that may be common in autism spectrum disorder and attention-deficit/hyperactivity disorder and facilitate the search for pleiotropic genes. Neurosci Biobehav Rev 2011 35:1363-1396.

2. Baron-Cohen S, Lombardo MV, Auyeung B, Ashwin E, Chakrabarti B, Knickmeyer R: Why are autism spectrum conditions more prevalent in males? PLOS Biol 2011, 9:e1001081.

3. Groenman AP, Oosterlaan J, Rommelse N, Franke B, Roeyers H, Oades RD, Sergeant JA, Buitelaar JK, Faraone SV: Substance use disorders in adolescents with attention deficit hyperactivity disorder: a 4-year follow-up study. Addiction 2013, 108:1503-1511.

4. Howlin P, Goode S, Hutton J, Rutter M: Adult outcome for children with autism. J Child Psychol Psychiatry 2004, 45:212-229.

5. Kent L, Emerton J, Bhadravathi V, Weisblatt E, Pasco G, Willatt LR, McMahon R, Yates JR: X-linked ichthyosis (steroid sulphatase deficiency) is associated with increased risk of attention deficit hyperactivity disorder, autism and social communication deficits. J Med Genet 2008, 45:519-524

6. Brookes KJ, Hawi Z, Kirley A, Barry E, Gill M, Kent L: Association of the steroid sulphatase (STS) gene with attention deficit hyperactivity disorder. Am J Med Genet B Neuropsychiatr Genet 2008, 147B:1531-1535.

7. Brookes KJ, Hawi Z, Park J, Scott S, Gill M, Kent L: Polymorphisms of the steroid sulphatase (STS) gene are associated with attention deficit hyperactivity disorder and influence brain tissue mRNA expression. Am J Med Genet B Neuropsychiatr Genet 2010, 153B:1417-1424.

8. Stergiakouli E, Langley K, Williams H, Walters J, Williams NM, Suren S, Giegling I, Wilkinson LS, Owen MJ, O'Donovan MC, Thapar A, Davies W: Steroid sulfatase is a potential modifier of cognition in attention deficit hyperactivity disorder. Genes Brain Behav 2011, 10:334-344.

9. Reed MJ, Purohit A, Woo LW, Newman SP, Potter BV: Steroid sulphatase: molecular biology, regulation, and inhibition. Endocr Rev 2005 26:171-202.

10. Penn AA: Early brain wiring: activity-dependent processes. Schizophr Bull 2001, 27:337-347.

11. Chaste P, Clement N, Botros HG, Guillaume JL, Konyukh M, Pagan C, Scheid I, Nygren G, Anckarsater H, Rastam M, Ståhlberg O, Gillberg IC, Melke J, Delorme R, Leblond C, Toro R, Huguet G, Fauchereau F, Durand C, Boudarene L, Serrano E, Lemière N, Launay JM, Leboyer M, Jockers R, Gillberg C, Bourgeron T: Genetic variations of the melatonin pathway in patients with attention-deficit and hyperactivity disorders. J Pineal Res 2011, 51:394-399.

12. Etain $B$, Dumaine $A$, Bellivier $F$, Pagan C, Francelle $L$, Goubran-Botros $H_{\text {, }}$ Moreno S, Deshommes J, Moustafa K, Le Dudal K, Mathieu F, Henry C, Kahn JP, Launay JM, Mühleisen TW, Cichon S, Bourgeron T, Leboyer M, Jamain S: Genetic and functional abnormalities of the melatonin biosynthesis pathway in patients with bipolar disorder. Hum Mol Genet 2012, 21:4030-4037

13. Galecki P, Szemraj J, Bartosz G, Bienkiewicz M, Galecka E, Florkowski A Lewinski A, Karbownik-Lewinska M: Single-nucleotide polymorphisms and mRNA expression for melatonin synthesis rate-limiting enzyme in recurrent depressive disorder. J Pineal Res 2010, 48:311-317.

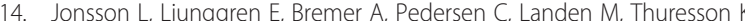
Giacobini M, Melke J: Mutation screening of melatonin-related genes in patients with autism spectrum disorders. BMC Med Genomics 2010, 3:10.

15. Melke J, Goubran Botros H, Chaste P, Betancur C, Nygren G, Anckarsater H, Rastam M, Stahlberg O, Gillberg IC, Delorme R, Chabane N, Mouren-Simeoni MC, Fauchereau F, Durand CM, Chevalier F, Drouot X, Collet C, Launay JM,
Leboyer M, Gillberg C, Bourgeron T: Abnormal melatonin synthesis in autism spectrum disorders. Mol Psychiatry 2008, 13:90-98.

16. Toma C, Rossi M, Sousa I, Blasi F, Bacchelli E, Alen R, Vanhala R, Monaco AP, Jarvela I, Maestrini E: Is ASMT a susceptibility gene for autism spectrum disorders? A replication study in European populations. Mol Psychiatry 2007, 12:977-979.

17. Wang L, Li J, Ruan Y, Lu T, Liu C, Jia M, Yue W, Liu J, Bourgeron T, Zhang D: Sequencing ASMT identifies rare mutations in Chinese Han patients with autism. PLoS One 2013, 8:e53727.

18. Veenstra-VanderWeele J, Blakely RD: Networking in autism: leveraging genetic, biomarker and model system findings in the search for new treatments. Neuropsychopharmacology 2012, 37:196-212.

19. Trent S, Dean R, Veit B, Cassano T, Bedse G, Ojarikre OA, Humby T, Davies W: Biological mechanisms associated with increased perseveration and hyperactivity in a genetic mouse model of neurodevelopmental disorder. Psychoneuroendocrinology 2013, 38:1370-1380.

20. Davies W, Humby T, Kong W, Otter T, Burgoyne PS, Wilkinson LS: Converging pharmacological and genetic evidence indicates a role for steroid sulphatase in attention. Biol Psychiatry 2009, 66:360-367.

21. Trent S, Dennehy A, Richardson H, Ojarikre OA, Burgoyne PS, Humby T, Davies W: Steroid sulfatase-deficient mice exhibit endophenotypes relevant to attention deficit hyperactivity disorder. Psychoneuroendocrinology 2012, 37:221-229.

22. Trent S, Cassano T, Bedse G, Ojarikre OA, Humby T, Davies W: Altered serotonergic function may partially account for behavioral endophenotypes in steroid sulfatase-deficient mice. Neuropsychopharmacology 2012, 37:1267-1274.

23. Vivien-Roels $B$, Malan A, Rettori MC, Delagrange $P$, Jeanniot JP, Pévet $P$ Daily variations in pineal melatonin concentrations in inbred and outbred mice. J Biol Rhythms 1998, 13:403-409.

24. ArrayExpress. [http://www.ebi.ac.uk/arrayexpress]

25. Isles AR, Davies W, Burrmann D, Burgoyne PS, Wilkinson LS: Effects on fear reactivity in $X O$ mice are due to haploinsufficiency of a non-PAR $X$ gene: implications for emotional function in Turner's syndrome. Hum Mol Genet 2004, 13:1849-1855.

26. Ebner MJ, Corol DI, Havlikova $\mathrm{H}$, Honour JW, Fry JP: Identification of neuroactive steroids and their precursors and metabolites in adult male rat brain. Endocrinology 2006, 147:179-190.

27. Sujkovic E, Mileusnic R, Fry JP: Metabolism of neuroactive steroids in day-old chick brain. J Neurochem 2009, 109:348-359.

28. SFARI Gene: a modular database for autism research. [https://gene.sfari. org/autdb/Welcome.do]

29. AutDB Autism Database. [http://autism.mindspec.org/autdb/Welcome.do]

30. ADHDgene: a genetic database for Attention Deficit Hyperactivity Disorder. [http://adhd.psych.ac.cn]

31. Mouse Genome Informatics. [http://www.informatics.jax.org]

32. Waage-Baudet H, Lauder JM, Dehart DB, Kluckman K, Hiller S, Tint GS, Sulik KK: Abnormal serotonergic development in a mouse model for the Smith-Lemli-Opitz syndrome: implications for autism. Int I Dev Neurosci 2003, 21:451-459.

33. Boulanger LM: Immune proteins in brain development and synaptic plasticity. Neuron 2009, 64:93-109.

34. Stevens B, Allen NJ, Vazquez LE, Howell GR, Christopherson KS, Nouri N, Micheva KD, Mehalow AK, Huberman AD, Stafford B, Sher A, Litke AM, Lambris JD, Smith SJ, John SW, Barres BA: The classical complement cascade mediates CNS synapse elimination. Cell 2007, 131:1164-1178.

35. Hagihara H, Takao K, Walton NM, Matsumoto M, Miyakawa T: Immature dentate gyrus: an endophenotype of neuropsychiatric disorders. Neural Plast 2013, 2013:318596.

36. Tabakoff B, Saba L, Kechris K, Hu W, Bhave SV, Finn DA, Grahame NJ, Hoffman PL: The genomic determinants of alcohol preference in mice. Mamm Genome 2008, 19:352-365.

37. Corbett BA, Kantor AB, Schulman H, Walker WL, Lit L, Ashwood P, Rocke DM, Sharp FR: A proteomic study of serum from children with autism showing differential expression of apolipoproteins and complement proteins. Mol Psychiatry 2007, 12:292-306.

38. Torrente F, Anthony A, Heuschkel RB, Thomson MA, Ashwood P, Murch SH: Focal-enhanced gastritis in regressive autism with features distinct from Crohn's and Helicobacter pylori gastritis. Am J Gastroenterol 2004, 99:598-605.

39. Torrente F, Ashwood P, Day R, Machado N, Furlano Rl, Anthony A, Davies SE, Wakefield AJ, Thomson MA, Walker-Smith JA, Murch SH: Small intestinal enteropathy with epithelial IgG and complement deposition in children with regressive autism. Mol Psychiatry 2002, 7:375-382. 
40. Segurado R, Conroy J, Meally E, Fitzgerald M, Gill M, Gallagher L: Confirmation of association between autism and the mitochondrial aspartate/glutamate carrier SLC25A12 gene on chromosome 2q31. Am J Psychiatry 2005, 162:2182-2184.

41. Rosenfeld JA, Ballif BC, Torchia BS, Sahoo T, Ravnan JB, Schultz R, Lamb A, Bejjani BA, Shaffer LG: Copy number variations associated with autism spectrum disorders contribute to a spectrum of neurodevelopmental disorders. Genet Med 2010, 12:694-702.

42. van der Zwaag B, Franke L, Poot M, Hochstenbach R, Spierenburg HA, Vorstman JA, van Daalen $E$, de Jonge MV, Verbeek NE, Brilstra EH, van't Slot $R$, Ophoff RA, van Es MA, Blauw HM, Veldink JH, Buizer-Voskamp JE, Beemer FA, van den Berg LH, Wijmenga C, van Amstel HK, van Engeland H, Burbach JP, Staal WG: Gene-network analysis identifies susceptibility genes related to glycobiology in autism. PLoS One 2009, 4:e5324.

43. Griswold AJ, Ma D, Cukier HN, Nations LD, Schmidt MA, Chung RH, Jaworski JM, Salyakina D, Konidari I, Whitehead PL, Wright HH, Abramson RK, Williams SM, Menon R, Martin ER, Haines JL, Gilbert JR, Cuccaro ML, Pericak-Vance MA: Evaluation of copy number variations reveals novel candidate genes in autism spectrum disorder-associated pathways. Hum Mol Genet 2012, 21:3513-3523.

44. Kaminsky EB, Kaul V, Paschall J, Church DM, Bunke B, Kunig D, Moreno-DeLuca D, Moreno-De-Luca A, Mulle JG, Warren ST, Richard G, Compton JG, Fuller AE, Gliem TJ, Huang S, Collinson MN, Beal SJ, Ackley T, Pickering DL, Golden DM, Aston E, Whitby H, Shetty S, Rossi MR, Rudd MK, South ST, Brothman AR, Sanger WG, lyer RK, Crolla JA, Thorland EC, Aradhya S, Ledbetter DH, Martin CL: An evidence-based approach to establish the functional and clinical significance of copy number variants in intellectual and developmental disabilities. Genet Med 2011, 13:777-784.

45. Prasad A, Merico D, Thiruvahindrapuram B, Wei J, Lionel AC, Sato D, Rickaby J, Lu C, Szatmari P, Roberts W, Fernandez BA, Marshall CR, Hatchwell E, Eis PS, Scherer SW: A discovery resource of rare copy number variations in individuals with autism spectrum disorder. G3 (Bethesda) 2012, 2:1665-1685.

46. Roubertoux PL, Carlier M, Degrelle H, Haas-Dupertuis MC, Phillips J, Moutier $\mathrm{R}$ : Co-segregation of intermale aggression with the pseudoautosomal region of the $Y$ chromosome in mice. Genetics 1994, 136:225-230.

47. Le Roy I, Mortaud S, Tordjman S, Donsez-Darcel E, Carlier M, Degrelle H, Roubertoux PL: Genetic correlation between steroid sulfatase concentration and initiation of attack behavior in mice. Behav Genet 1999, 29:131-136.

48. Nicolas LB, Pinoteau W, Papot S, Routier S, Guillaumet G, Mortaud S: Aggressive behavior induced by the steroid sulphatase inhibitor COUMATE and by DHEAS in CBA/H mice. Brain Res 2001, 922:216-222.

49. Chamero P, Marton TF, Logan DW, Flanagan K, Cruz JR, Saghatelian A, Cravatt BF, Stowers L: Identification of protein pheromones that promote aggressive behaviour. Nature 2007, 450:899-902.

50. Nicolas LB, Fry JP: The steroid sulphatase inhibitor COUMATE attenuates rather than enhances access of dehydroepiandrosterone sulphate to the brain in the mouse. Brain Res 2007, 1174:92-96.

doi:10.1186/2040-2392-5-21

Cite this article as: Trent et al:: Altered brain gene expression but not steroid biochemistry in a genetic mouse model of neurodevelopmental disorder. Molecular Autism 2014 5:21.

\section{Submit your next manuscript to BioMed Central and take full advantage of:}

- Convenient online submission

- Thorough peer review

- No space constraints or color figure charges

- Immediate publication on acceptance

- Inclusion in PubMed, CAS, Scopus and Google Scholar

- Research which is freely available for redistribution 